\title{
Assessment of traditional ecological knowledge and beliefs in the utilisation of important plant species: The case of Buhanga sacred forest, Rwanda
}

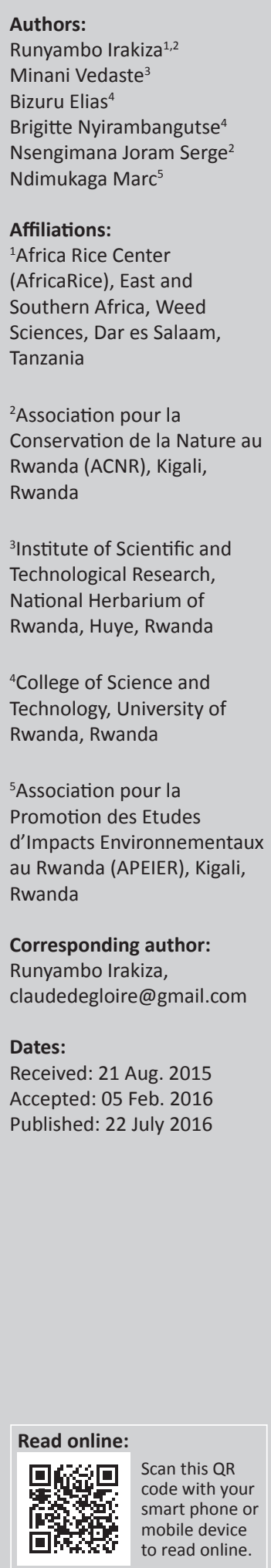

Traditional ecological knowledge is an integrated part of the African people and indeed the Rwandese for cultural purpose. Buhanga sacred forest is a relict forest of tremendous ecological importance to Rwandan society located in Musanze District. The aim of this study was to assess the traditional ecological knowledge and belief in the utilisation of some important plant species for the conservation of Buhanga sacred forest. Ecological information about ethnomedicinal and traditional practices were collected following structured questionnaire through interview involving eight traditional healers and three focus group discussions. Data were collected from the natural habitats, home gardens, farmlands and roadsides of Buhanga sacred forest. A total of 45 botanical taxa belonging to 28 families were reported to be used by the local community. Species such as Brillantaisia cicatricosa and Senna septemtrionalis were the popular species cited by traditional healers to treat human and animal diseases and ailments, respectively. The results of the study indicated that because of the cultural norms and values associated with the sacred forest, this has led to non-exploitation. The study presents key sites and plant species in which their use and belief can lead to their conservation. However, not only is it imperative to conserve traditional local knowledge for biocultural conservation motives but there is also need to train traditional healers on how to domesticate indigenous species as conservation measure because some species have become susceptible to extinction.

Conservation implications: Highlighting indigenous species investigated in this research will provide a powerful tool for ensuring biodiversity conservation through community participation in a country of high population density in Africa. Some plant species that provided satisfactory Local Health Traditions among communities surrounding Buhanga can contribute as good material for further research in Rwanda.

\section{Introduction}

Traditional ecological knowledge is defined as a cumulative body of knowledge, practice and belief. It is a mutual relationship between living beings (including humans) and its environment which evolves by adaptive processes and are handed down through generations by cultural transmission (Berkes 1999). Such knowledge has contributed to conservation of biodiversity (Gadgil, Berkes \& Folke 1993), rare species (Colding 1998) and protected areas (Johannes 1998) as well as to sustainable resource use (Berkes 1999) from one area to another. In Africa, there are important elements to take into account regarding indigenous or traditional spirituality towards the nature. The value of traditional knowledge of natural resources is widely recognised among indigenous people because it was accumulated and transferred orally across generations. According to Charnley, Paige and Jones (2007) and Berkes, Colding and Folke (2000), the integral success of the traditional ecological knowledge into biodiversity conservation depends on active participation of the knowledge holders, such as indigenous communities and institutions. To avoid loss of biodiversity, traditional rules play an important role when developing conservation strategies for rare species by limiting illegal activities such as selective trees felling (Ormsby 2013). Some sacred species constitute excellent totems. Totems are often plants or animals that are a stand-in of its owner and their presence dissuade from illegal access to sacred areas. Furthermore, these sacred species contribute significantly in conservation by acting as umbrella species to the overall ecosystem (Ndimukaga 2009). Sacred place functions under the principle of faith and fear of god and other supernatural forces. This principle requires honesty, respect of ancestors and observation of moral values (Kamga-Kamdem 2008).

How to cite this article: Irakiza, R., Vedaste, M., Elias, B., Nyirambangutse, B., Serge, N.J. \& Marc, N., 2016, 'Assessment of traditional ecological knowledge and beliefs in the utilisation of important plant species: The case of Buhanga sacred forest, Rwanda', Koedoe 58(1), a1348. http://dx.doi.org/10.4102/koedoe.v58i1.1348

Copyright: ( 2016. The Authors. Licensee: AOSIS. This work is licensed under the Creative Commons Attribution License. 


\section{Rwandan culture history and forest}

In many sub-Saharan African societies, the traditional ecological knowledge among indigenous people is synonymous with spirituality, which contributed to sustain the sacred forests. Rwanda, one of the smallest countries in the world with only $26,338 \mathrm{~km}^{2}$, has a rich forest heritage. The value of Rwandan culture is based on oral history, ecology and nature, geographical sites and by igitaramo. Igitaramo constitutes a gathering of families, communities and friends with songs and dances. During pre-colonial time, Rwandan society was inherently linked to forest, which hides great lessons concerning rites, ancestral customs, taboos, arts, crafts, music, dance and many more. Such integral links led to the emergence of traditional medicine (Karangwa 1997). The Rwandese are aware of the existence of these traditional healers who provide home-based healthcare. Locally, they are known as abavuzi gakondo or abapfumu. The former denotes traditional healers involved in the use of plants and the latter denotes those who are involved especially in the ritual component of traditional medicine (Rwangabo 1993). But it has been said that sometimes abapfumu use leaves, roots or barks of plants to protect their clients in exchange for money (Adenkule 2007). As a matter of fact, traditional ecological knowledge is still very much alive in Rwanda because it contributes significantly to solve health problems. In Rwanda, cutting of certain tree species is seen as a taboo as well as killing of indigenous animal such as primates, elephants, leopards, birds, etc. According to Kimenyi (1989), thisconservationemphasised thesymbioticand interdependence relationship between people, plants and animals. It is for these reasons that cultural values are an essential component of every society and they act as checks and balances in the management of natural resources (Verschuuren et al. 2010).

\section{The context of Buhanga sacred forest}

Buhanga sacred forest is a relict forest of tremendous ecological importance to Rwandan's society for cultural purposes. It lies in volcanic belt and has one of the highest population density in Rwanda and Africa, with up to 500-700 people per $\mathrm{km}^{2}$ (NISR 2012; Plumptre, Masozera \& Vedder 2001). Buhanga relict forest contains sacred water-spring, marshland, medicinal plants, native trees and even a last refuge for arboreal, migratory birds. For example, African Pitta Pitta angolensis is a migrant bird that breeds in central Tanzania, Malawi, southeast Democratic Republic of Congo, eastern Zambia, Zimbabwe and possibly northern South Africa that was sighted in Buhanga sacred forest (BirdLife International Africa Partnership e-bulletin 2008). Unfortunately, reports indicate that this relict forest is facing many threats as a result of human interference on the environment in various ways, such as harvesting of firewood and agriculture (MINITERE \& CGIS-NUR 2007; REMA 2009). In fact, high pressure of disturbance of natural reserves in Rwanda was noticed until the resettlement of refugees after the genocide during the year 1997-1998 where people both settled and farmed within many natural reserves (Plumptre et al. 2001). It should be mentioned that in most cases natural resources are still viewed as limitless in the mind of the resource-poor local communities in Rwanda as a source of income. However, it should be seen furthermore that without any practical actions for sustainable utilisation of so-called 'limitless resources' and usage of traditional ecological knowledge, there is a risk of genetic loss and lack of traditional information from generation with time.

To address the issue of loss of this critical cultural forest in Rwanda, the goal of this study is to document the traditional ecological knowledge and belief in the utilisation of some important plant species of Buhanga sacred forest. Hence, there is a need for such information and documentation with the help of local communities to develop comprehensive and useful strategies for public awareness but also to formulate recommendations for monitoring natural resources for better future (Figure 1).

\section{Material and methods Geo-ethnographical overview of the study area}

Buhanga sacred forest is an archaic forest located in Northern Province, District of Musanze, Nkotsi sector and Bikara cell, at the right side of the road that leads towards Vunga business centre. The site is situated at approximately $114 \mathrm{~km}$ from Kigali, the capital city of Rwanda and covers an area of 33.252 ha, of which 16.0011 ha is still intact and located between $1{ }^{\circ} 34^{\prime} 00^{\prime \prime}$ and $1^{\circ} 34^{\prime} 30^{\prime \prime}$ South latitude and $29^{\circ} 34^{\prime} 30^{\prime \prime}$ and $29^{\circ} 37^{\prime} 30^{\prime \prime}$ East longitude at an altitude ranging between $1623 \mathrm{~m}$ a.s.l. and $1657 \mathrm{~m}$ a.s.l. Geo-climatically the area falls within the tropical rainforest of the volcano massif where climate is controlled by various factors such as altitude, latitude and vegetation. The climate is cool and wet and temperatures fluctuate around $20{ }^{\circ} \mathrm{C}$ during the day. Most of the lands surrounding Buhanga sacred forest are used for agriculture subsistence. Near subsistence agriculture, coffee, tea and pyrethrum plantations are prominent land uses as cash crop generating local employment. Projects funds from government and international non-governmental organisations have been used for a range of activities from environment protection (tree planting, soil erosion control and beekeeping) to limit access in the sacred forest (Figure 2).

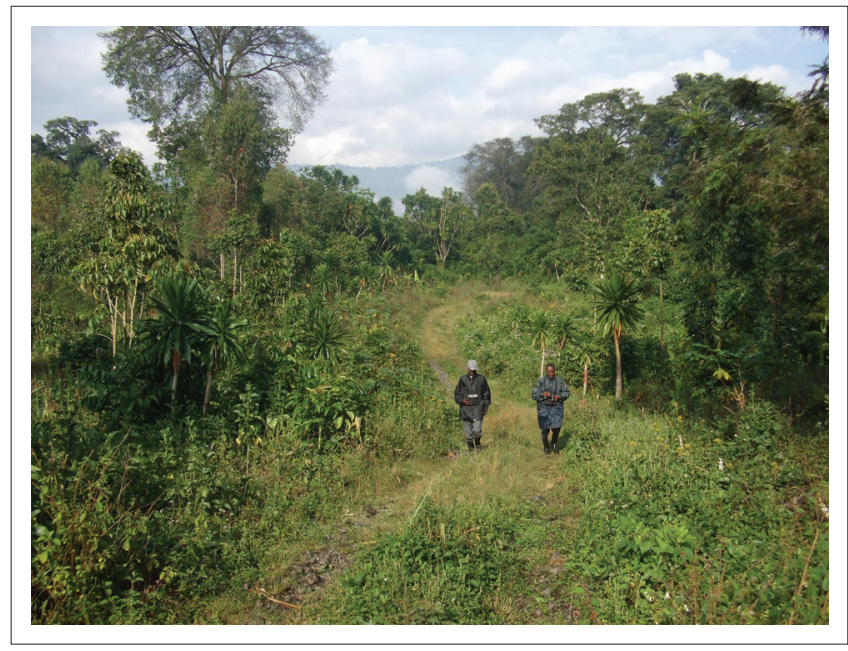

Source: Association for the Conservation of Nature in Rwanda, 2008 FIGURE 1: View of Buhanga sacred forest. 


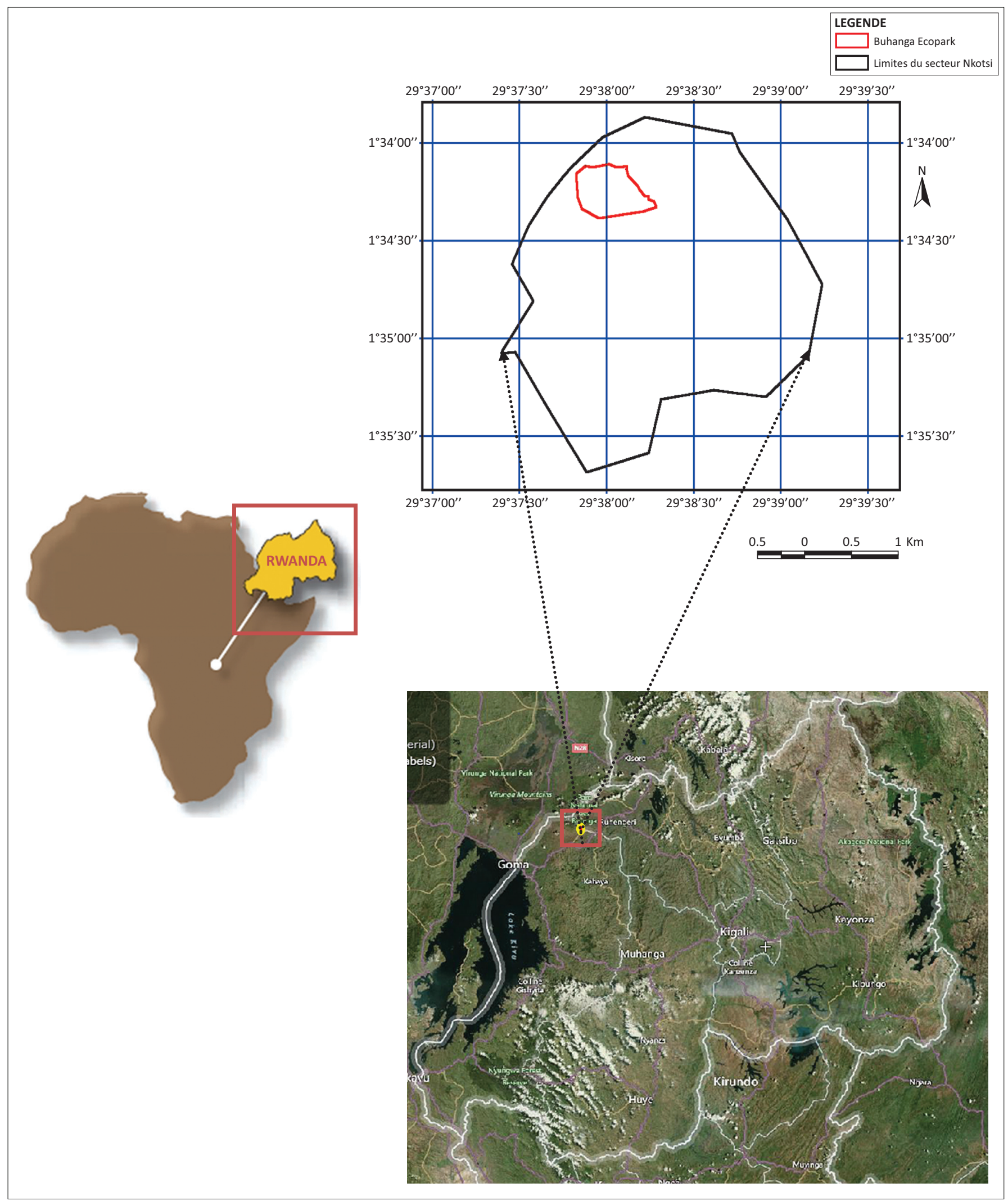

Source: Google Earth and GPS points by Iraguha, 2004 FIGURE 2: Map of the study area. 


\section{Ethnobotanical survey}

Our study was carried out during the period of 26-31 May, 2008. A reconnaissance survey was conducted in Abadahemuka cooperative at Nkotsi-Bikara, Musanze District. In Rwanda, most of the traditional healers are grouped into cooperatives under the supervision of the Ministry of Health in close collaboration with the Institute of Scientific and Technological Research. The traditional healers provided the information about traditional healing practices for both humans and animals, while the elders provided information regarding rituals and beliefs surrounding the forest. The information regarding the use of medicinal plants was collected following structured questionnaire through interviews involving eight traditional healers (five men and three women) aged between 41 and 80 years. These traditional healers were recognised by the local government authorities and selected based on their reputation on herbal medicinal uses. Plant species mentioned by traditional healers were visited inside the relict forest and home gardens to verify the reliability of data obtained during interviews (Alexiades 1996; Gerique 2006). The recorded field data include the following: collection number, plant local name, scientific name, habit, plant parts used, mode of preparation, habitat and locality (Martin 1995). The information regarding the traditional practices and utilisation of Buhanga sacred forest were captured through three focus discussion groups. Each discussion group comprised 15 persons (10 men and 5 women) who were natives of the Nkotsi-Bikara village aged between 50 and 80 years; inclusion was based on a good knowledge of Buhanga sacred forest history. During the discussion, each member of the group took about 5-8 min to talk about the importance of cultural knowledge and use of Buhanga sacred forest.

Species information provided either during the interview or group discussion were recorded. When a species was physically observed in home garden and not in the forest and vice versa, the information regarding that species was collected. Species recognised only through vernacular names without physical identification either in home garden or in the forest was considered unreliable and rejected. Species botanical identification was carried out in the National Herbarium of Rwanda using voucher specimens, identification keys, field guides and the flora of Rwanda (Troupin 1966, 1978, 1982, 1983, 1985, 1988; and Fischer \& Dorothee 2008) (see picture showing different sites of study area in Appendix 1).

\section{Data analysis}

Validation of plant names, family and plant authority were carried out using the Royal Botany Garden and Missouri Botanic Garden plant names database (http://www. theplantlist.org).

Collected data were analysed using descriptive statistics. The determination of relative frequency of citation of reported medicinal plant species was done using the following formula:
$\operatorname{RFC}(\%)=(\mathrm{FC} / \mathrm{N}) \times 100$

[Eqn 1]

where, FC is the number of informants mentioning the use of medicinal plant species and $\mathrm{N}$ is the total number of informants participating in the survey.

\section{Results Plant diversity}

This study recorded 45 plant species that were used by local communities in the vicinity of Buhanga sacred forest. Of the 45 species, 38 plant species were categorised in 34 genera and 19 families to have medicinal value. In terms of species composition of medicinal plants, the family of Asteraceae, Acanthaceae and Fabaceae had three species each followed by the family of Chenopodiaceae, Rutaceae, Rhamnaceae, Ranunculaceae, Polygonaceae, Solanaceae, Menispermaceae, Verbenaceae, Urticaceae and Cucurbitaceae with two species each. The remaining 14 families were represented by a single species each (see Figure 3). Regarding life form, 21 species $(47 \%)$ were herbs, 8 species $(18 \%)$ were trees, 10 species $(22 \%)$ were climbers, 4 species (8\%) were shrubs and 2 species (4\%) were grasses (see Figure 4).

\section{Plant species role in ecological, social and cultural welfare}

Results of medicinal plants collected from different habitats show that most of the plant species, about 29 species (62.22\%) were harvested from natural vegetation followed by 9 species $(20.00 \%)$ under cultivation in home gardens, 6 species $(13.33 \%)$ collected in farming plots and 2 species $(4.44 \%)$ found near the roadsides. The goods and uses of the vegetation in our study area showed that most of the plant species are used for medicinal purposes (38 plant species [74.51\%]) followed by raw materials (8 species [15.69\%]), social symbol (3 species [5.88\%]) and 2 species (3.92\%) for spiritual purpose (see Figure 5 and Table 1).

Interviewees from the three group discussions recounted stories of transgressors who had taken resources from a sacred forest and misfortunes fell on them (see Table 2). For example it was said that villagers would not dare to enter the Buhanga sacred forest for fear of angering some spirits in control of the forest. They believe that these spirits were able to curse them by sending a resident giant snake protective of the surrounding marshland called igishanga cya gihanga. Moreover, Buhanga sacred forest is a habitat for many rare species of snakes which upon sight a curse follows. Calamities such as drought were also associated by such omens.

\section{Medicinal flora}

Of the 38 plant species reported to have medicinal uses, 29 species distributed in 19 families were reported to be used against human health problems, six species belonging to six families were used against cattle diseases and three species belonging to three families were used against both human and cattle diseases. The most striking diseases recorded in 17 human health problems were the poison vomiting treated by 


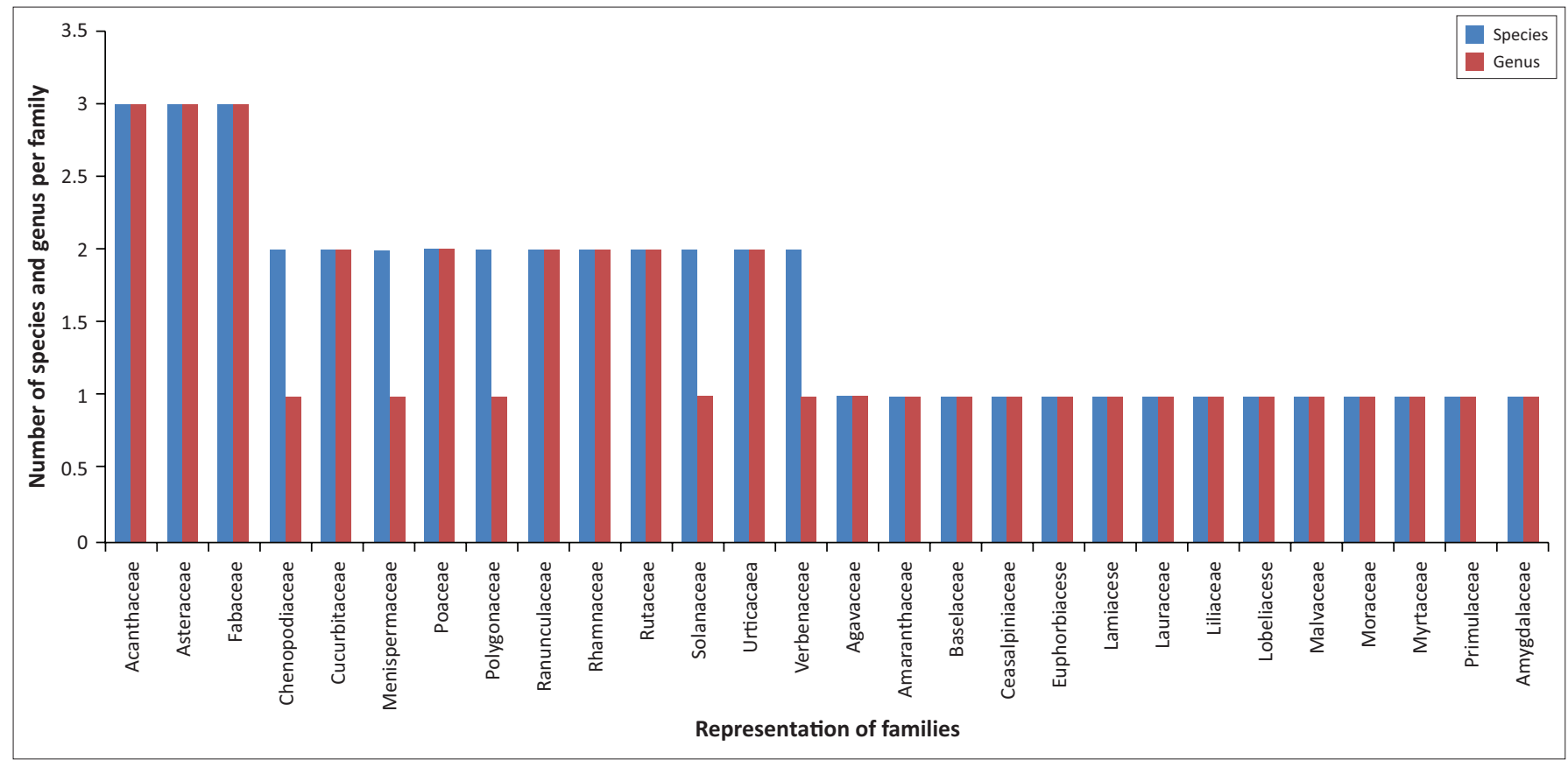

Source: Association for the Conservation of Nature in Rwanda, 2008

FIGURE 3: Distribution of 45 identified plant species among botanical families.

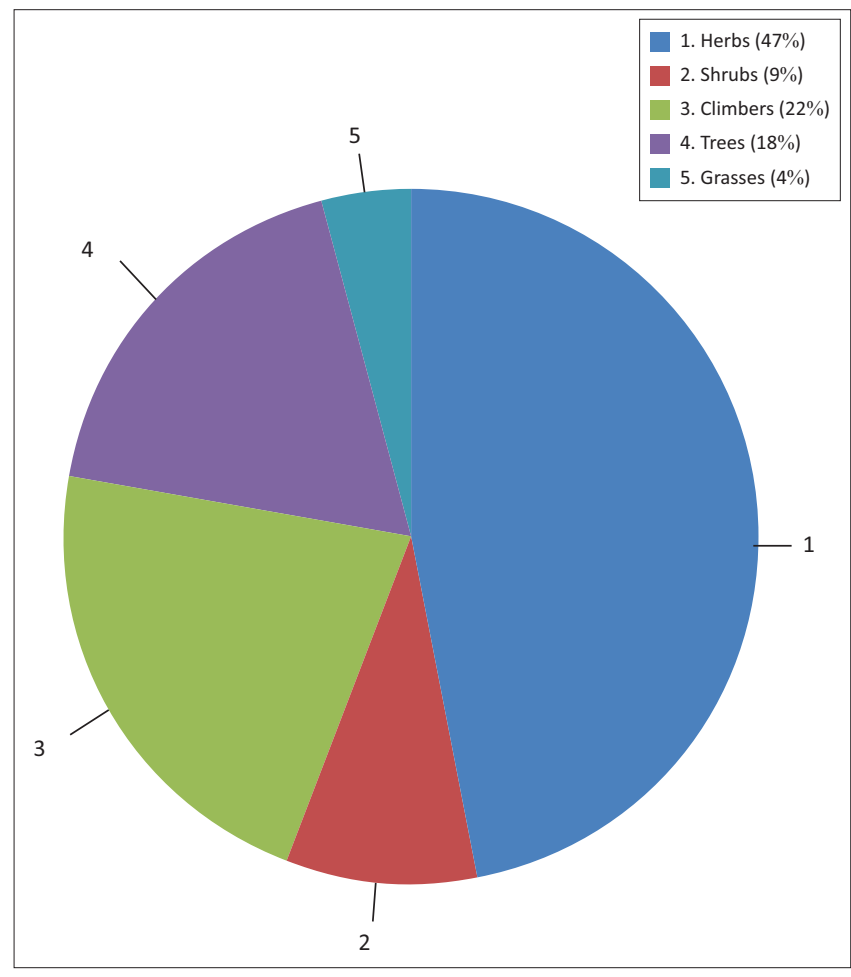

Source: Association for the Conservation of Nature in Rwanda, 2008

FIGURE 4: Life form proportion of plant species.

six plant species followed by mental diseases and Kilondatumbo (Symptoms of Kilondatumbo: painful sensation in the digestive system with presence of ulcers in the ileum and rectum) treated with five specific plant species (Table 3). Stomach ache was treated by three plant species while other plant species were used to treat one or two diseases (see Table 3). In regard to ethnoveterinary medicine, the most remarkable diseases were tick-borne diseases (East coast fever, Babesiosis and Anaplasmosis) treated by four species followed by sexual

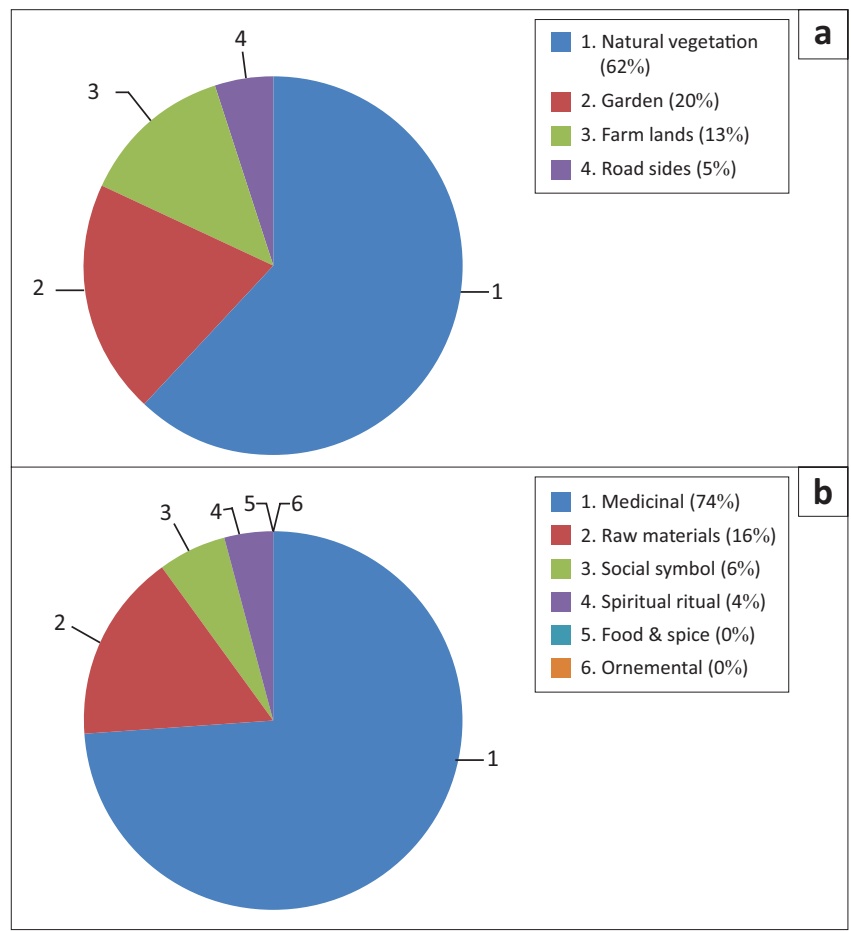

Source: Association for the Conservation of Nature in Rwanda, 2008 FIGURE 5: (a) Origin of medicinal plants and (b) social welfare of plant species.

dysfunction treated by two species. All other diseases were treated by one species each (see Table 4 ).

Regarding of some medicinal plants popular than others, Brillantaisia cicatricosa was the most popular plant cited by 5 traditional healers for it medicinal value (Relative frequency of citation $[\mathrm{RFC}]=62.5 \%$ ) followed by three plant species Senna septemtrionalis, Thalictrum rhynchocarpum and Solanum terminale mentioned by 4 traditional healers (RFC $=50 \%$ ). The species Zanthoxylum sp., Rumex abyssinicus, Prunus africana, 
TABLE 1: Plant species uses by local communities as raw material.

\begin{tabular}{llllll}
\hline Scientific name & Family & $\begin{array}{l}\text { Vernacular name } \\
\text { (Kinyarwanda) }\end{array}$ & Life form & Part used & Utilisation (Kinyarwanda) \\
\hline Stephania abyssinica (Dill. \& Rich.) Walp & Menispermaceae & Umuhanda & Liana & Stem & Traditional plate (inkoko) \\
Triumphetta rhomboidea Jacq. & Malvaceae & Umusarenda & Shrub & Stem & Ceiling (Idari) \\
Pennissetum purpureum S humach. & Poaceae & Urubingo & Grass & Stem & Ceiling (Idari) \\
Stephania cyanantha Welw. ex Hiern & Menispermaceae & Umwifuzo & Liana & Stem & Vans (ibigega) \\
Gouania longispicata Engl & Rhamnaceae & Umusando & Liana & Stem or leaves & Basket (Ibitebo) \\
Urera hypselodendron (A. Rich.) Wedd. & Urticaceae & Umuse & Liana & Stem & Traditional mats (Ibirago) \\
Clerodendrum rotundifolium Oliv. & Verbenaceae & Umuziranyenzi & Liana & Stem & Straw for drinking the traditional beer (Umuheha, Imikenke) \\
Ficus thonningii Blume & Moraceae & Umuvumu & Tree & Stem & Vat for fermentation of banana wine \\
\hline
\end{tabular}

TABLE 2: Name of sites and species of spiritual importance among local people.

\begin{tabular}{|c|c|c|}
\hline Sites and species & Importance & Brief history \\
\hline Caves & Place for spiritual rituals & $\begin{array}{l}\text { Caves of Buhanga sacred forest are spiritual ritual places for local people. Before the colonisation, } \\
\text { it is said that Rwandan kings always spend one night in caves before the first investiture the } \\
\text { following day }\end{array}$ \\
\hline Igishanga cya gihanga (marshland) & $\begin{array}{l}\text { Place for spiritual rituals outside the } \\
\text { sacred forest }\end{array}$ & $\begin{array}{l}\text { Place for spiritual rituals for local communities. They believe that the marshland is protected by a } \\
\text { giant snake avoiding the forest from drought. The rare appearance of the snake is a prediction of } \\
\text { a bad event }\end{array}$ \\
\hline Dracaena steudneri Engl. & Social symbol & $\begin{array}{l}\text { A piece of bark of the species is burned and charcoals are used to burry single people (unmarried } \\
\text { people/single) at the funeral }\end{array}$ \\
\hline Ficus thonningii Blume & $\begin{array}{l}\text { Social and spiritual symbol } \\
\text { (respectful tree) }\end{array}$ & $\begin{array}{l}\text { The species is planted at the entry of the main gate } \\
\text { - as a symbol of keeping something valuable (heritage) to remain in the family } \\
\text { as a symbol for showing the personality (respect) of the family }\end{array}$ \\
\hline Erythrina abyssinica Lam. ex Dc. & Social and spiritual protection & The species is planted as spiritual protection against evil spirits in the compound of the house \\
\hline
\end{tabular}

Ranunculus multifidus, Tragia brevipes, Urtica massaica and Ajuga alba were mentioned by 3 informants ( $\mathrm{RFC}=37.5 \%$ ) while Chenopodium opulifolium, Cyathula cylindrica, Solanum aculeastrum and Solanecio mannii were mentioned by only 2 traditional healers ( $\mathrm{RFC}=25 \%$ ) (see Tables $3 \& 4)$.

Concerning plant parts used frequently for medicinal preparation, the leaves were the most used parts followed by both leaves and tree barks in human health problem representing $81 \%$ and $6 \%$ respectively. Regarding the ethnoveterinary medicine the leaves were also the most plant part used followed by both roots and tree barks and flowers representing $78 \%$ and $11 \%$ each. The majority of remedies were prepared in the form of juice from freshly collected plant parts. The juice was prepared by pounding or crushing a plant part in a wooden or stone motor and pesters. Water was the most liquid substance used to dilute the prepared juice. The remedies were taken orally, accounting $84 \%$ of medicinal plants use, followed by external application applied typically on skin representing $8 \%$ and $5 \%$ on ear application except remedies from the species Eucalyptus maidenii giving anally as smoke to treat haemorrhoids and fresh leaves from $T$. brevipes rubbing on painful join to treat rheumatism accounting both 3\% (see Figure 6).

\section{Discussion}

Taking consideration the size of Buhanga sacred forest, there is a high percentage of plants being naturally harvested in the forest by local communities. The fact that more than a half of remedies were prepared from herbs in natural habitat than cultivated or home gardens indicates that the natural area of Buhanga sacred forest is very important for local communities to satisfy their home-based healthcare. Our finding is similar to the finding of Edwards (2004) reporting that $2 / 3$ of medicinal plants used worldwide are harvested from the natural environment. During interview, traditional healers reported that more medicinal plants were harvested previously than now in Buhanga sacred forest and some species formerly forest-habiting species are now rarely encountered in the area. This is the case of the species $P$. africana that became extinct in the natural forest while C. cylindrica still existed occasionally due to overharvesting in the past. Studies involving Rwanda on medicinal plants reveal decline of these resources (Stewart 2003).

Our research findings revealed that the poison vomiting, mental diseases and Kilondatumbo in human health problems were the most cited diseases in our study area because remedies against these three predominant health problems were mostly prepared. In a situation where several drugs in one area are required, this indicates a prepotency of a particular disease (Dawit \& Ahadu 1993). The potential of medicinal plants recorded in this study were also confirmed by other research conducted elsewhere in Rwanda (Dessouter 1991; Kamagaju et al. 2013; Kayonga \& Habiyaremye 1987; Mbarubukeye \& Niang 1996; Rwangabo 1993). As per the ethnoveterinary medicine represented mostly by tick-borne diseases, suggests that these diseases were very important in the area. According to Byavu et al. (2000), Mbarubukeye (1991) and Van Puyvelde et al. (1985), the East Coast fever (theileriosis) played a vital role in cattle mortality in Rwanda, particularly in exotic pure breed crossing with the Ankole breed while anaplasmosis and babesiosis represented an enormous cost in term of time and money. Also study conducted by Nshimiyimana and Mutandwa (2010) indicates that damages attributable to ticks borne diseases in Rwanda 
TABLE 3: Medicinal plants used against human health problems.

\begin{tabular}{|c|c|c|c|c|c|c|c|c|c|}
\hline Family & Scientific name & Vernacular name & Life form & Substance & Medicinal indication & $\begin{array}{l}\text { Plant part } \\
\text { used }\end{array}$ & $\begin{array}{l}\text { Route of } \\
\text { administration }\end{array}$ & $\begin{array}{l}\text { Mode of } \\
\text { preparation }\end{array}$ & RFC \\
\hline \multirow[t]{3}{*}{ Acanthaceae } & Barleria grandicalyx Lindau. & Bugangabukari & Herb & Juice & Child bellybutton & Leaves & Oral & Demw & 12.5 \\
\hline & Asystasia sp. & Akanyamapfundo & Herb & Juice & Mental trouble & Leaves & Oral & $\mathrm{Cmw}$ & 12.5 \\
\hline & Brillantaisia cicatricosa Lindau. & $\begin{array}{l}\text { Kirogora, } \\
\text { Ikinyamugere }\end{array}$ & Herb & Juice & Mental trouble & Leaves & Oral & $\mathrm{Cmw}$ & 62.5 \\
\hline Agavaceae & Dracena steudneri Engl. & Igihondohondo & Tree & Powder & Mental trouble & Tree bark & Oral & $\mathrm{Cmw}$ & 12.5 \\
\hline \multirow[t]{2}{*}{ Amygdalaceae } & Prinus africana (Hook. f.) Kalkm. & Umwumba & Tree & Juice & Dysentery & Leaves & Oral & $\begin{array}{l}\text { Cm Aloe vera } \\
4 \text { cswbj }\end{array}$ & 37.5 \\
\hline & & & & Powder & Stomach aches & Tree bark & Oral & Demw & 12.5 \\
\hline \multirow[t]{3}{*}{ Asteraceae } & Bidens pilosa $\mathrm{L}$. & Inyabarasanya & Herb & Juice & Mental trouble & Leaves & Oral & $\mathrm{Cmw}$ & 12.5 \\
\hline & Gynura scandens O. Hoffm. & Kizimyamuriro & Liana & Juice & Kilondatumbo ${ }^{\dagger}$ & Leaves & Oral & $\mathrm{Cmw}$ & 12.5 \\
\hline & $\begin{array}{l}\text { Solanecio mannii (Hook.f.) C. } \\
\text { Jeffrey }\end{array}$ & Umutagara & Herb & Juice & Poison vomiting & Leaves & Oral & $\mathrm{Cmw}$ & 25 \\
\hline Ceasalpiniaceae & $\begin{array}{l}\text { Senna septemtrionalis (Viv.) } \\
\text { Irwin \& Barneby (Syn: Cassia } \\
\text { floribunda Cav.) }\end{array}$ & Umukubanzoka & Shrub & Juice & Intestinal worm & Leaves & Oral & $\mathrm{Cmw}$ & 50 \\
\hline \multirow[t]{2}{*}{ Chenopodiacece } & $\begin{array}{l}\text { Chenopodium opulifolium Auct. } \\
\text { Non-schrad. }\end{array}$ & Umugombe & Herb & Juice & $\begin{array}{l}\text { Muscle disease, } \\
\text { Kilondatumbo }\end{array}$ & Leaves & Oral & $\mathrm{Cmw}$ & 25 \\
\hline & $\begin{array}{l}\text { Chenopodium procerum Hochst. } \\
\text { ex Moq. }\end{array}$ & Umwisheke & Herb & Juice & Muscle disease & Leaves & Oral & $\mathrm{Cmw}$ & 12.5 \\
\hline \multirow[t]{2}{*}{ Cucurbitaceae } & Zehneria scabra (L.F.) Sonder & Umushishiro & Liana & Juice & Mumps & Leaves & Ear & $\mathrm{Cmw}$ & 12.5 \\
\hline & Momordica foetida Schum. & Umwishwa & Liana & Juice & Poison vomiting & Leaves & Oral & $\mathrm{Cmw}$ & 12.5 \\
\hline \multirow[t]{2}{*}{ Euphorbiaceae } & Tragia brevipes Pax. & Isusa & Herb & Juice & Gonorrhoea, Diarrhoea & Leaves & Oral & $\mathrm{Cmw}$ & 37.5 \\
\hline & & & & Fresh leaves & Rheumatism & Leaves & Joint pain & Rlpj & 12.5 \\
\hline \multirow[t]{3}{*}{ Fabaceae } & $\begin{array}{l}\text { Desmodium repandum (Vadhl) } \\
\text { Dc. }\end{array}$ & Ituza & Herb & Juice & $\begin{array}{l}\text { Heart trouble, Poison } \\
\text { vomiting }\end{array}$ & Leaves & Oral & $\mathrm{Cmw}$ & 12.5 \\
\hline & Erythrina abyssinica Lam. & Umuko & Tree & Powder & $\begin{array}{l}\text { Mental disease } \\
\text { Kilondatumbo }\end{array}$ & Tree bark & Oral & Demw & 12.5 \\
\hline & Cajanus cajan (L.) MIIlsp. & Umukunde & Herb & Juice & Mumps & Leaves & Ear & $\mathrm{Cmw}$ & 12.5 \\
\hline Lamiaceae & Ajuga alba (Guerke) Robyns & Igitingwa & Herb & Juice & Poison vomiting & Leaves & Oral & $\mathrm{Cmw}$ & 37.5 \\
\hline Lauraceae & Persea americana Milier. & Ivoca & Tree & Juice & Stomach trouble & Fruit & Oral & $\mathrm{Cmw}$ & 12.5 \\
\hline Liliaceae & Aloes sp. & Igikakarubamba & Herb & Juice & Diarrhoea & Leaves & Oral & $\mathrm{Cmw}$ & 12.5 \\
\hline Myrtaceae & Eucalyptus maidenii F.Muell & Inturusu & Tree & Smoke & Haemorrhoids & Bark & Anal & Bbwlspp & 12.5 \\
\hline Polygonaceae & Rumex abyssinicus Jacq. & Umufumbageshi & Herb & Juice & Kilondatumbu† & Leaves & Oral & Dcmw & 12.5 \\
\hline Primulaceae & Lysimachia ruhmeriana Vatke. & Umuyobora & Herb & Juice & Stomach trouble & Leaves & Oral & Demw & 12.5 \\
\hline \multirow[t]{3}{*}{ Ranunculaceae } & Ranunculus multifidus Forskk. & Kazingashya & Herb & Juice & Fracture, & Leaves & Broken part & Cmwai & 37.5 \\
\hline & & & & Powder & Poison vomiting & Leaves & Oral & Dcmw & 12.5 \\
\hline & $\begin{array}{l}\text { Thalictrum rhynchocarpum } \\
\text { Dillon ex. A. Rich }\end{array}$ & Ubugomboro & Herb & Juice & Snakebites & Leaves & Oral & $\mathrm{Cmw}$ & 50 \\
\hline \multirow[t]{2}{*}{ Rhamnaceae } & Gouania longispicata Engl. & Umusando & Liana & Juice & Foetal trouble & Leaves & Oral & $\mathrm{Cmw}$ & 12.5 \\
\hline & Rhamnus prinoides Lihert. & $\begin{array}{l}\text { Umunanira, } \\
\text { umusasa }\end{array}$ & Tree & Juice & Poison vomiting & Leaves & Oral & $\mathrm{Cmw}$ & 12.5 \\
\hline \multirow[t]{2}{*}{ Rutaceae } & $\begin{array}{l}\text { Clausena anisata (Willd) Hook. F } \\
\text { ex. Benth }\end{array}$ & Umuzo & Shrub & Juice & Varicela, scabies & Leaves & Skin lesions & $\mathrm{Cmw}$ & 12.5 \\
\hline & Zanthoxylum sp. (Engl.) & Intare y'irungu & Tree & $\begin{array}{l}\text { Powder, } \\
\text { Juice }\end{array}$ & Gonorrhoea & Tree bark & Oral & $\mathrm{Cmw}$ & 37.5 \\
\hline Solanaceae & Solanum terminale Forsskal. & Umuhanurankuba & Herb & Juice & Placenta retention & Leaves & Oral & $\mathrm{Cmw}$ & 37.5 \\
\hline Urticacaea & Urtica massaica Mild Br. & Igisura & Herb & Juice & Gonorrhoea & Roots & Oral & $\mathrm{Cmw}$ & 37.5 \\
\hline Verbenaceae & Clerodendrum fuscus Guerke & Umumara & Liana & Juice & Poison vomiting & Leaves & Oral & $\mathrm{Cmw}$ & 12.5 \\
\hline
\end{tabular}

RFC, Relative frequency of citation; Cmw, Crushed and mixed with water; Cm Aloe vera 4cswbj, Crushed and mixed with Aloe vera (4 coffee spoons) then swallow with banana juice; Dcmw, Dried, crushed and mixed with water; Rlpj, Rubbing the leaves on the painful joints; Bbwlspp, Boil the bark with water and lead the smoke with a small plastic pipe; Cmwai, Crushed and mixed with water then applied immediately.

Kilondatumbu †, painful sensation in the digestive system with presence of ulcers in the ileum and rectum.

were considered as the first economic damage of bovine production transmitting sucking blood parasites diseases such as theileriosis, anaplasmosis and babesiosis.

With more than $70 \%$ of leaves use as ingredient in making of medicinal concoction indicates that leaves are more required to solve the health problem in our study area. In reference to Dawit and Ahadu (1993) and Poffenberger et al. (1992), the normal harvesting leaves estimated of up to $50 \%$ does not significantly affect the growth of plant species or does not cause a great danger to existence of individual plant when compared to the collection of underground part, stem or whole plant from both ecological points of view and survival of species. The extinction of $P$. africana as reported by the healers is due to overutilisation of both its leaves and barks as ingredients and was replaced by agricultural activities. The same were reported by Sayer, Harcourt and Collins (1992) Stewart (2003) and MINITERE (2003). In general there was no really threat of overharvesting of plant in Buhanga sacred forest as it used to be in the past because the remedies are prepared and used locally, and therefore harvested in small quantities. Traditional healers reported that they do not store remedies for a prolonged period of time because when the need comes, they go out to collect plants, prepare the remedies and use it for treatment. However the importance of Buhanga were known a long time ago, this sacred forest has acquired since 2005 a status of 
TABLE 4: Plants used in veterinary medicine.

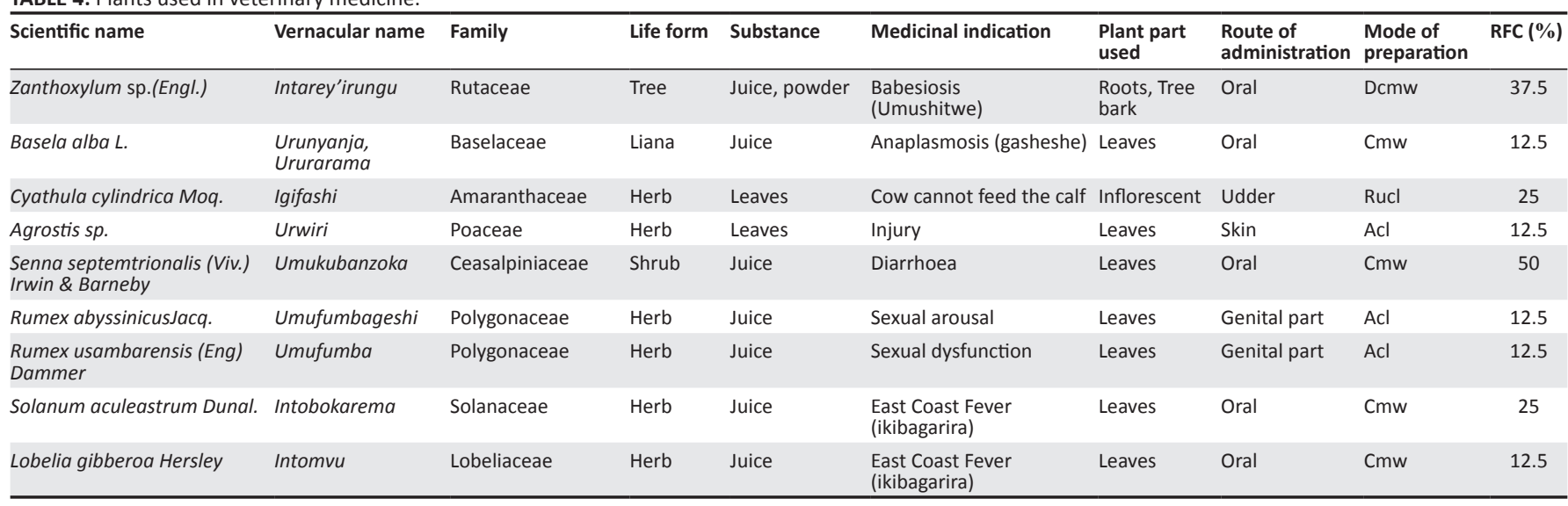

Dcmw, Dried, crushed and mixed with water; Cmw, Crushed and mixed with water; Rucl, Rubbing the udder of cow with leaves; Acl, Apply crushed leaves; RFC, Relative frequency of citation.

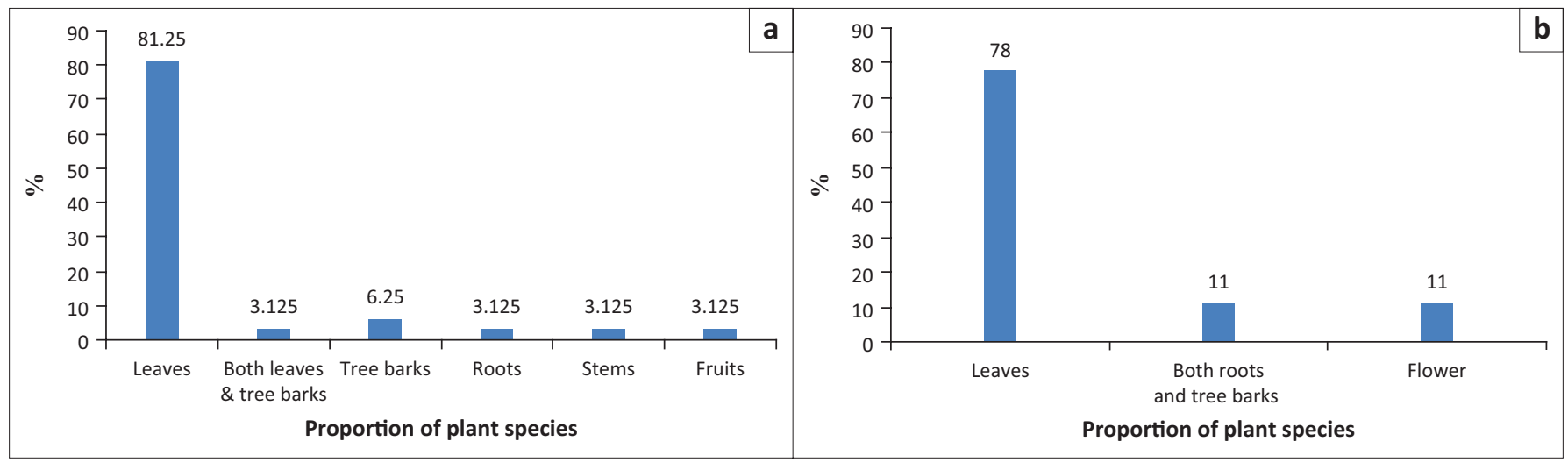

Source: Association for the Conservation of Nature in Rwanda, 2008

FIGURE 6: Proportion of plant parts used for human and cattle health problems: (a) Proportion of plant parts used for human health problems; (b) proportion of plant parts used for cattle health problems.

protected area as a part of the Volcanoes National Park from the former Rwanda Office of Tourism and National Parks (ORTPN), now Rwanda Development Board (RDB) (REMA 2009). In the same context, culture and spiritual beliefs plays an important aspect in the conservation of Buhanga sacred forest. Recently, water springs from Buhanga are still used as source of clean water for local people in the area and caves and some tree species (Dracaena steudneri, Erythrina abyssinica and Ficus thonningii) are important for their ritual and ceremonies.

\section{Conclusion}

This study has revealed the importance of traditional ecological knowledge in Buhanga sacred forest plays a vital role in our heritage. The high plant diversity used in traditional medicine to treat different ailments was localised mostly in the natural habitat and does not really present threat of overharvesting because remedies are prepared on a need-to-need basis. Also this study has shown how cultural values and beliefs are crucial tools for conservation and should therefore be incorporated in all management plans of Buhanga sacred forest.

In light of this research finding, we recommended that traditional healers should be trained on how to domesticate natural plant species as some of them has becoming rare or extinct in the surrounding area due to past anthropogenic activities. Among others 15 species were documented and reported in our study area as priority species for preservation of stored grains for their medicinal importance uses. These include: B. cicatricose, S. septemtrionalis, T. rhynchocarpum, S. terminale, Zanthoxylum sp., R. abyssinicus, P. africana, R. multifidus, T. brevipes, U. massaica, A. alba, C. opulifolium, C. cylindrica, S. aculeastrum and S. mannii.

\section{Acknowledgements}

This study was funded by the regional non-governmental organisation (NGO) of Albertine Rift (ARCOS) in partnership with Association pour la Conservation de La Nature au Rwanda (ACNR). We thank the National Herbarium of Rwanda for their support in species identification and other relevant botanical information, the local government authorities' of Musanze District and traditional healers, members of Abadahemuka cooperative. Special thanks go to Ir. Gloriose Barebwayire from Projet d'Appui du Développement de l'Élevage Bovin Laitier (PADEBL/MINAGRI) for excellent technical support in cattle diseases identification, Mrs Usambyimbabazi Madeleine, a student at the National University of Rwanda (NUR)-Botany Department for her kind field assistance and Mr Felix M. Waweru (AfricaRice Center - Dar es Salaam) for editing and proof-reading. 


\section{Competing interests}

The authors declare that they have no financial or personal relationships which may have inappropriately influenced them in writing this article.

\section{Authors' contributions}

N.J.S. was the project leader, M.V., B.E. and B.N. made conceptual contribution, N.M. was involved in data collection and R.I. was responsible for data collection and analysis, writing up the article and project design.

\section{References}

Adenkule, J.O., 2007, Culture and customs of Rwanda, Greenhood Press, London.

Alexiades, M.N., 1996, Collecting ethnobotanical data: An introduction to basic concepts and techniques, Institute of Economic Botany, The New York Botanical Garden, New York, viewed 20 October 2013, from http://www.academia. edu/446138/Alexiades_M._1996._Collecting_ethnobotanical_data

Association pour la Conservation de la Nature au Rwanda, 2008, Biodiversity survey of Buhanga relict forest. Report, ACNR, Kigali, Rwanda.

Berkes, F., 1999, in F. Berkes (ed.), 'Sacred ecology: Traditional ecological knowledge and resource management', in Chapter I: Context of Traditional Ecological Knowledge (Part I, Concept), p. 209, Taylor and Francis, Philadelphia, PA

Berkes, F., Colding, J. \& Folke, C., 2000, 'Rediscovery of traditional ecological knowledge as adaptive management', Ecological Applications 10(5), 1251-1262, viewed 12 January 2015, from http://www.fws.gov/nativeamerican/pdf/tekberkes-2000.pdf

BirdLife International Africa Partnership e-bulletin, 2008, 'An African Pitta Pitta angolensis pays a visit to Buhanga relict forest, Rwanda' $\left(16^{\text {th }}\right.$ e-bulletin June 2008), viewed 24 November 2015, from http://www.birdlife.org/sites/default/ files/attachments/16th\%20ebulletin\%20June\%202008_final.pdf

Byavu, N., Henrard, C., Dubois, M. \& Malaisse, F., 2000, 'Phytothérapie traditionnelle des bovins dans les élevages de la plaine de la Ruzizi', Biotechnology, Agronomy, www.researchgate.net/publication/26392451_Phytothrapie_traditionnelle_des bovins_dans_les_levages_de_la_plaine_de_la_Ruzizi

Charnley, S., Paige, A.F. \& Jones, T.E., 2007, 'Integrating traditional and local ecological knowledge into forest biodiversity conservation in the Pacific Northwest', Forest Ecology and Management 246, 14-28. http://dx.doi.org/10.1016/j.foreco.2007. 03.047

Colding, J., 1998, 'Analysis of hunting options by the use of general food taboos', Ecological Modelling 110, 5-17. http://dx.doi.org/10.1016/50304-3800(98)00038-6

Dawit, A. \& Ahadu, A., 1993, Medicinal plants and enigmatic health practices of Northern Ethiopia, Birhanna Selam Printing Enterprise, Addis Ababa, Ethiopia.

Dessouter, S., 1991, Pharmacopée humaine et vétérinaire du Rwanda. Annales Sciences Economiques 22, Institut National de Recherche Scientifique, Butare, Rwanda, Musée Royal de l'Afrique Centrale Tervuren.

Edwards, R., 2004, 'No remedy in sight for herbal ransacks', New Science 181, 10-11.

Fischer, E. \& Killmann, D., 2008, Illustrated Field Guide to the Plants of Nyungwe National Park, Rwanda. Koblenz Geographical Colloquia, Series Biogeographical Monographs 1: 1-772, Germany.

Gadgil, M., Berkes, F. \& Folke, C., 1993, 'Indigenous knowledge for biodiversity conservation', Ambio 22, 151-156.

Gerique, A., 2006, An introduction to ethnoecology and ethnobotany theory and Methods. Integrative assessment and planning methods for sustainable agroforestry in humid and semiarid regions, Department of Geography, University of Giessen, Senckenbergstr, Germany, viewed 28 October 2013, from https:// www.researchgate.net/publication/239591352 An Introduction to wWw. researchgate. net/publication/239591352 An Introduction to
ethnoecology and ethnobotany Theory and Methods - Integrative assessment and_planning methods_for_sustainable_agroforestry_in humid and_semiarid_regions

Iraguha, G., 2004, Database of Rwanda and GPS point of Buhanga relict forest, in Association pour la Conservation de la Nature au Rwanda, 2008, Biodiversity survey of Buhanga relict forest, Report, ACNR, Kigali, Rwanda.

Johannes, R.E., 1998, 'The case for data-less marine resource management: Examples from tropical nearshore fisheries', Trends in Ecology and Evolution 13, 243-246. http://dx.doi.org/10.1016/S0169-5347(98)01384-6

Kamagaju, L., Bizuru, E., Minani, V., Morandini, R., Stévigny, C., Ghanen, G. et al., 2013 'An ethnobotanical survey of medicinal plants used in Rwanda for voluntary depigmentation', Journal of Ethnopharmacology 150, 708-717, viewed 26 November 2015, from http://www.sciencedirect.com/science/article/pii/S037 8874113006788
Kamga-Kamdem S.L., 2010, 'Ancestral Beliefs and Conservation: The Case of Sacred Sites in Bandjoun, West Cameroon', in B. Verschuuren, R. Wild, J.A. McNeely and G. Oviedo (eds.), Sacred Natural Sites. Conserving Nature \& Culture, pp. 120-128, G. Oviedo (eds.), Sacred Natural Sites. Conserth
Earthscan Ltd. London and Washington DC.

Karangwa, C., 1997, Validating traditional knowledge: Rwanda. Institute of Scientific and Technological Research (IRST), General information, Butare, Rwanda, viewed 28 December 2012, from http://tcdc2.undp.org/GSSDAcademy/SIE/Docs/Vol10/ V10_S3_ValidKnowledge.pdf

Kayonga, A. \& Habiyaremye, F.X., 1987, Médecine traditionnelle et plantes médicinales rwandaises, Contribution aux études ethnobotaniques de la flore rwandaise, Préfecture de Gisenyi, Univ. Nat. Rwanda Centre universitaire de recherche sur la pharmacopée et la médecine traditionnelle, CURPHAMETRA, inédit, p. 121.

Kimenyi, A., 1989, Kinyarwanda and Kirundi Names: A semiotic analysis of Bantu onomastics, The Edwin Mellen Press, New York.

Martin, G.J., 1995, Ethnobotany: People and plants conservation manuals, Chapman and Hall, London.

Mbarubukeye, S., 1991, 'Immunization against East Coast fever in Rwanda: Ticks and tick-borne diseases control', Proceedings of a joint OAU, FAO and ILRAD workshop held in Kampala, Uganda, The International Laboratory for Research on Animal Diseases, Kenya, September 12-14, 1991, viewed 02 December 2012, from hiseases, Kenya, September $12-14$, 1991.usaid.gov/pdf_docs/PNABS630.pdf
http

Mbarubukeye, S. \& Niang, A.I., 1996, Les usages particuliers des plantes ligneuses agroforestières autochtones du Rwanda; Utilisation en médecine traditionnelle humaine et vétérinaire, en alimentation humaine, en apiculture et en artisanat, Rubilizi.

MINITERE, 2003, National strategy and action plan for the conservation of biodiversity in Rwanda, Ministry of Lands Resettlement and Environment, Republic of Rwanda, Kigali, p. 44, viewed 23 December 2013, from http://www.vub.ac.be/ klimostoolkit/sites/default/files/documents/bd_policy_rwanda.pdf

MINITERE \& CGIS-NUR, 2007, Final report on the Mapping of Rwandese forests, Vol. 1. The Ministry of Lands, Environment, Forests, Water and Natural Resources (MINITERE) and The Geographic Information Systems \& Remote Sensing Research and Training Center of the National University of Rwanda (CGIS - NUR).

Ndimukaga, M., 2009, Non timber wetland products and their sustainable use: Case of Rugezi Wetland, Rwanda, Association pour la conservation de la Nature au Rwanda and Alcoa foundation, Kigali, Rwanda, report, p. 15.

NISR, 2012, Population and housing census-November 2012, National Institute of Statistics of Rwanda (NISR)-Republic of Rwanda, Kigali, viewed 14 December 2012 from https://www.statistics.gov.rw/system/files/user_uploads/files/books/2012 Census_Final_Draft.pdf

Nshimiyimana, J. \& Mutandwa, E., 2010, 'Seasonal dynamics and distribution of ticks in Rwanda: Implications for tick control strategy in Rwanda', International Journa of Animal and Veterinary Advances 2(1), 21-25, viewed 13 August 2015, from http://maxwellsci.com/print/ijava/v2-21-25.pdf

Ormsby, A., 2013, 'Analysis of local attitudes toward the sacred groves of Meghalaya and Karnataka, India', Conservation and Society 11, 187-197, viewed 19 November 2015, from http://www.conservationandsociety.org/temp/Conservat Soc1121874854658_132906.pdf

Plumptre, A.J., Masozera, M. \& Vedder, A., 2001, The impact of civil war on the conservation of protected areas in Rwanda. Washington, DC: Biodiversity Support Program (BSP).

Poffenberger, M., McGean, B., Ravindranath, N.H. \& Gadgil, M., 1992, 'Field methods manual, Volume II. Community Forest Economy and Use Pattern: Participatory Rural Appraisal (PRA) Metho Wasteland Development', in J.A. Sayer, C.S. Harcourt \& N.M. Collins (eds.), The conservation atlas of tropical forests: Africa, pp. 288, Macmillan, Basingstoke.

REMA, 2009, Rwanda State of Environment and outlook: Chap II. Population, Health and human settlements, Rwanda Environment Management Authority (REMA),
Kigali, viewed 11 November 2015, from http://rema.gov.rw/soe/chap2.php

Rwangabo, P.C., 1993, La médicine traditionnelle au Rwanda, Edition Karthala, ACCT, Paris.

Sayer, A.J., Harcourt, C.S. \& Collins, N.M., 1992, 'The conservation atlas of tropical forests: Africa', in J.A. Sayer, C.S. Harcourt \& N.M Collins (eds.), Part II: Country studies, p. 104, Macmillan Publishers Ltd., London, United Kingdom, viewed 21 December 2014, from https://archive.org/details/conservationatla92sa

Stewart, K.M., 2003, 'The African cherry (Prunus africana): Can lessons be learned from an over-exploited medicinal tree?', Journal of Ethnopharmacology 89, 3-13, viewed 11 November 2012, from http://www.sciencedirect.com/science/article/ pii/S037887410300299X

Troupin, G., 1966, Etude phytocénotique du Parc National de l'Akagera et du Rwanda oriental, Institut National de Recherche Scientifique (INRS), Butare.

Troupin, G., 1978-1988, Flore du Rwanda: Vols 1-4. Musée Royal de l'Afrique Centrale. Tervuren and Institut National de Recherche Scientifique, Butare.

Van Puyvelde, L., Geysen, D., Ayobangira, F.X., Hakizamungu, E., Nshimiyimana, A. \& Kalisa, A., 1985, 'Screening of medicinal plants of Rwanda for acaricidal activity', Journal of Ethnopharmacology 13, 209-215. http://dx.doi.org/10.1016/03788741(85)90008-X

Verschuuren, B., Wild, R., McNeely, J. \& Gonzalo, O., 2010, Natural sites conserving nature and culture, International Union for Conservation of Nature (IUCN), Earthscan Press, pp. 20-32, London and Washington DC. 


\section{Appendix 1}
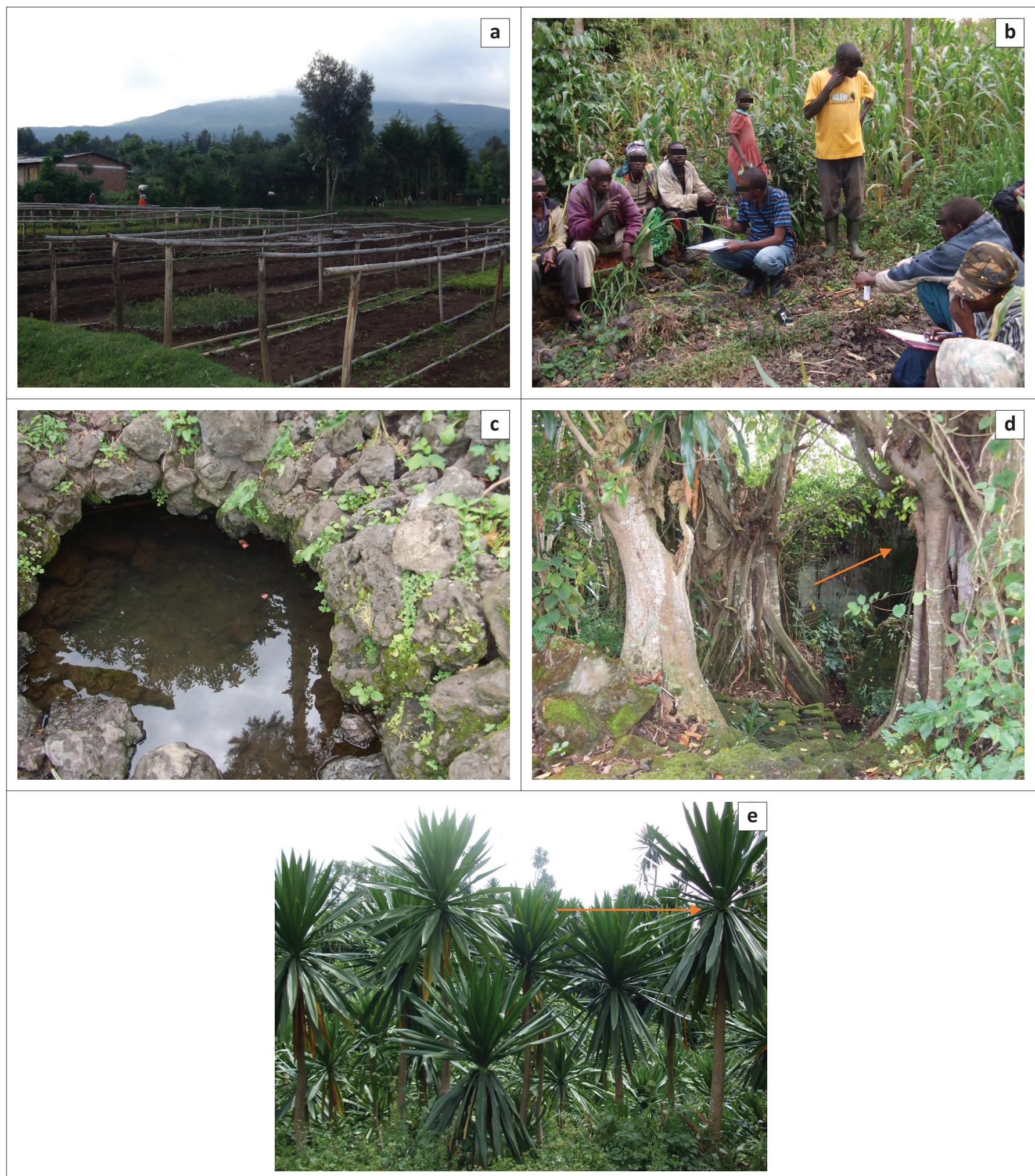

Source: Association for the Conservation of Nature in Rwanda, 2008

FIGURE 1-A1: (a) Photo showing the village surrounding the study area, (b) one of the group discussion with local indigenous, (c) and some important sites and species of Buhanga sacred forest including the mysterious water-spring, (d) cave (e) and Dracaena steudneri (Igihondohondo). 


\section{REMARKABLE EXPERIENCES REMARKABLE PLACES}

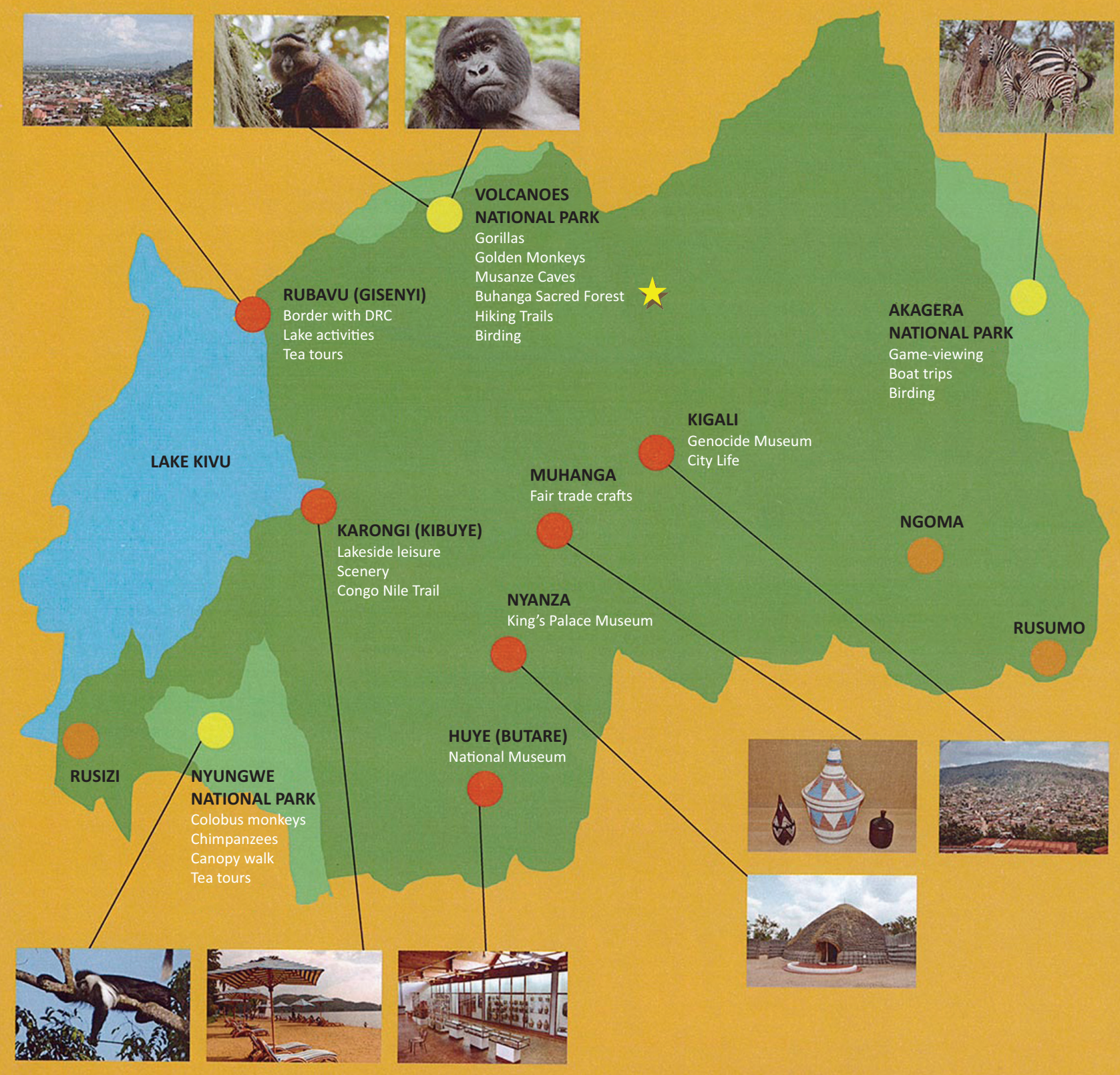

